Gut, 1963, 4, 367

\title{
$\mathrm{ABO}$ Blood groups in relation to duodenal ulceration among the Yorubas of western Nigeria
}

\author{
W. W. DAVEY AND E. A. ElEBUte \\ From the Department of Surgery, University College, Ibadan
}

EDITORIAL SYNOPSIS This paper shows that in Nigeria as in England there is an excess of blood group $\mathrm{O}$ in patients with duodenal ulcer.

Data collected from 12 hospitals in England led Aird, Bentall, Mehigan, and Roberts (1954) to draw the conclusion that persons of blood group $\mathrm{O}$ were about $35 \%$ more likely to develop peptic ulceration than persons of the other groups. This association has been confirmed by Clarke, Cowan, Edwards, Howel-Evans, McConnell, Woodrow, and Sheppard (1955) and by many others. Aird et al. quoted Buchanan and Higley (1921) as the first to discover the relationship, their series being derived from the Mayo Clinic. This paper deals with duodenal ulceration alone as gastric ulceration has been found to be very rare in Western Nigeria by Joly (1956) and by Barton and Cockshott (1961).

\section{COLLECTION OF DATA}

The patients with duodenal ulcer were those treated in the Department of Surgery from 1957 till May 1962; they are consecutive and were selected on account of their need of surgery. Only patients in whom the ulcers were convincingly demonstrated at operation and a small number seen at necropsy during the same period were included in the series. The controls were derived from the general population as represented by the blood donors at the Blood Transfusion Unit of University College Hospital, Ibadan, the figures being culled from the annual report (1960) of the hospital's Department of Pathology.

\section{RESULTS}

The blood group distribution in the control series of 19,257 Yorubas and in the 421 Yoruba patients with duodenal ulceration is shown in the Table.
TABLE

BLOOD GROUPS OF CONTROLS AND OF PATIENTS WITH DUODENAL ULCER

\begin{tabular}{|c|c|c|}
\hline \multirow[t]{2}{*}{ Blood Group } & Control & Duodenal Ulcer \\
\hline & No. & No. \\
\hline $\begin{array}{l}\mathbf{O} \\
\mathbf{A} \\
\mathbf{B} \\
\mathbf{A B}\end{array}$ & $\begin{array}{rr}9,876 & (51 \cdot 3 \%) \\
4,166 & (21.6 \%) \\
4,454 & (23.1 \%) \\
761 & (4.0 \%)\end{array}$ & $\begin{array}{r}238(56.5 \%) \\
89(21.1 \%) \\
86(20.4 \%) \\
8(1.9 \%)\end{array}$ \\
\hline Total & $19,257(100 \cdot 0 \%)$ & $421(99.9 \%)$ \\
\hline
\end{tabular}

The relative incidence of duodenal ulcer in persons of blood group $\mathrm{O}$ compared with the incidence of persons in the other blood groups is $1 \cdot 30 . \chi^{2}$ is calculated to 4.602 , which for $n=1$ gives $0.02<$ $p<0.05$. The difference between the two groups is therefore statistically significant.

\section{CONCLUSION}

If this series is typical, it may be concluded that Yorubas with blood group $\mathrm{O}$ are much more likely by approximately $30 \%$ to develop duodenal ulcers than those belonging to other blood groups.

\section{REFERENCES}

Aird, I., Bentall, H. H., Mehigan, J. A., and Roberts, J. A. F. (1954) The blood groups in relation to peptic ulceration and carcinoma of colon, rectum, breast, and bronchus. Brit. med. J., 2 , 315-321.

Barton, C. J., and Cockshott, W. P. (1961). Post-bulbar duodenal ulceration in Nigeria. Brit. J. Radiol., 34, 216-220.

Buchanan, J. A., and Higley, E. T. (1921). The relationship of blood-groups to disease. Brit. J. exp. Path., 2, 247-255.

Clarke, C. A., Cowan, W. K., Edwards, J. W., Howel-Evans, A. W. McConnell, R. B., Woodrow, J. C., and Sheppard, P. M. (1955). The relationship of ABO blood groups to duodenal and gastric ulceration. Brit. med. J., 2, 643-646.

Joly, B. M. (1956). Peptic ulcer in Western Nigeria and Sou:hern United States. W. Afr. med. J., 5, 55-63. 